\title{
Utilization of diverse cheap materials as pore generating agent to manufacture low-cost porous ceramic
}

\section{(Utilização de diversos materiais baratos como agente gerador de poros na fabricação de cerâmica porosa de baixo custo)}

\author{
M. M. Salman ${ }^{1}$, N.S. Radhi ${ }^{1}$, O. H.Sabr ${ }^{1}$,H.T. Nhabih ${ }^{1 *}$ \\ ${ }^{\prime}$ Babylon University, Faculty of Materials Engineering, Babylon, Iraq
}

\begin{abstract}
Paper waste, corn starch, and sawdust were utilized as pore generating agents to produce a porous ceramic. Kaolin clay, sodium feldspar, and $20 \%$ of pore generating agent were mixed, and the samples were formed by mold method, dried at room temperature for about $72 \mathrm{~h}$ and in a furnace at $115^{\circ} \mathrm{C}$ for $5 \mathrm{~h}$, and then fired at $1200{ }^{\circ} \mathrm{C}$ with a soaking time of $3 \mathrm{~h}$. The samples were tested for measurement of physical and mechanical properties and the microstructure was evaluated by scanning electron microscopy and mercury intrusion porosimetry. The results showed that the sample prepared with corn starch had the highest porosity, lowest mechanical properties and permeability, and smallest pore size, while the characteristics of the sample prepared with sawdust were contrary; finally, the sample of paper waste had the highest permeability and intermediate values of other properties.
\end{abstract}

Keywords: porous ceramics, paper waste, corn starch, sawdust.

\section{Resumo}

Resíduo de papel, amido de milho e serragem foram utilizados como agentes geradores de poros para produzir uma cerâmica porosa. Argila caulinítica, feldspato sódico e $20 \%$ de agente gerador de poros foram misturados e as amostras foram conformadas pelo método do molde, secas à temperatura ambiente por cerca de $72 \mathrm{~h}$ e em forno a $115{ }^{\circ} \mathrm{C}$ por $5 \mathrm{~h}$, e depois queimadas a $1200{ }^{\circ} \mathrm{C}$ com um tempo de patamar de $3 \mathrm{~h}$. As amostras foram ensaiadas para medição das propriedades físicas e mecânicas e a microestrutura foi avaliada por microscopia eletrônica de varredura e porosimetria por intrusão de mercúrio. Os resultados mostraram que a amostra preparada com amido de milho apresentou a maior porosidade, menores propriedades mecânicas $e$ permeabilidade, e menor tamanho de poro, enquanto as características da amostra preparada com serragem foram contrárias; finalmente, a amostra de resíduo de papel apresentou a maior permeabilidade e valores intermediários de outras propriedades. Palavras-chave: cerâmica porosa, resíduo de papel, amido de milho, serragem.

\section{INTRODUCTION}

The recycling of some waste materials in the ceramic manufacturing has been widely studied in recent years, in order to economically justify the great costs related to its manufacture as well as to avoid the landfill of these wastes [1-5]. Porous ceramic has many fields of application, ranging from catalyst supports to filters for molten metals, hightemperature thermal insulation, separators in electrochemical reactors, bioreactors and bone tissue engineering, lightweight sandwich structures, microporous membranes for water purification, and wastewater treatment. Also, porous ceramic preforms are utilized for the preparation of ceramicpolymer and ceramic-metal composites [6]. Ceramics can outperform their polymer and metal competitors for many applications due to their relatively low density, which means lightweight, corrosion resistance, including hot corrosive liquids and gases, thermal stability, chemical inertness, and

*eng.hussein.t@uobabylon.edu.iq

Dhttps://orcid.org/0000-0003-3071-4998 high-temperature structural stability [7]. Ceramics have excellent mechanical and thermal properties that have been widely used for tribological applications [8].

Depending on the intended application, the requirements of the ceramic microstructures are different. For example, the fluid transport with fluids ranging from gases to suspensions requires open pores and permeability, and separation efficiency depends on the degree of pore opening, connectivity, size, cross-section shape, and uniformity. Thermal insulation requires closed pores, and the thermal conductivity for porous ceramic may be lower than that of air, as the pore size is small enough, nanosized, i.e., lower than the mean free path for the gas particles enclosed. On the other hand, porous bioceramics for bone ingrowth require open pores with a high degree of connectivity and a small pore size in the range of 100 to $200 \mu \mathrm{m}$, and catalyst supports are often in the form of functionally graded material systems with a layered structure of variable porosity and/or pore size and a top layer with a high surface area. Rather special applications exist for porous ceramic with tailored electrical properties. For example, porous piezoelectric ceramic is 
advantageous for medical imaging and hydrophones, due to its improved pairing with liquid or biological tissue because of the matching of the acoustic impedance [9]. The production of porous ceramic often comprises a material that decomposes through the thermal treatment of sintering by melting, evaporation, decomposition, or burning [10]. For example, the decomposition of urea described in [11], the melting and vaporization of poly(methyl methacrylate) studied in [12], or the burning of flour researched in [13]. The variety of substances utilized to generate porosity in ceramics is large [10]. The use of a temperature-sensitive substance to generate porosity in support is employed in the fabrication of membranes of advanced ceramics such as zirconia, titania, and alumina, and traditional compositions with sawdust [14], and local raw materials such as clay [15] and perlite [16]. Various substances have been utilized as pore formers beginning with natural products such as poppy seeds [17], rice bran [18], and palm fibers [19], going through chemically pure materials such as urea [11] and ending in treated materials such as corn starch [20] or wastes such as fly ash [21] and sawdust [14].

In the present study, a paper waste, corn starch, and sawdust were used as a pore-forming agent with kaolin clay and sodium feldspar to produce a low-cost porous ceramic. The clay consisted of kaolinite, which gave plasticity to the green paste and was the precursor of mullite crystals [22]. The materials used as a poreforming agent in this study were cheap, easy to burn, nontoxic, and environmentally non-hazardous [10]. Starch is largely used as a substance to generate porosity in the ceramic body since it produces pores through burning out at about $500{ }^{\circ} \mathrm{C}[20,23,24]$. Also, the paper waste is one of the environmental problems of solid wastes, where it is one of the common problems from which the countries suffer, due to its harmful effects on the environmental and general health [25]. The paper waste and sawdust are solid wastes, and they are employed to form pores in ceramics during the firing stage. This study aims to prepare, compare, and determine the material which can be more suitable between diverse cheap kinds of materials used as a pore generating agent to manufacture low-cost porous ceramic. The use of three different types of materials as a pore generating agent in the same clayey mass gives the chance to study the sample properties without varying the ratio of the raw materials or the processing variables through the experiments, and it gives the chance to compare between these properties to determine the material which provides an excellent combination to the mechanical and physical properties in the ceramic.

\section{MATERIALS AND METHODS}

In this study, paper waste, corn starch, and sawdust were used as a pore-forming agent with kaolin clay used as matrix material and sodium feldspar used as flux material to produce low-cost porous ceramics. Na-feldspar was used to obtain acceptable mechanical properties for the porous ceramic body because it contributes to the densification of the fired ceramic materials. Although the use of Na-feldspar reduces the porosity of the samples, it is beneficial to obtain an acceptable combination of mechanical properties and porous structure for the samples.

Data of raw materials and residues: an Iraqi kaolin clay was used as matrix material; its chemical composition is shown in Table I, while the physical properties are shown in Table II. As pore-forming agents, the paper waste used was residues of the paper used for writing; the sawdust used was taken from residuals of the wood obtained from big trees and its dry density was $1.63 \mathrm{~g} / \mathrm{cm}^{3}$, and moisture content was $16.7 \mathrm{wt} \%$; and the corn starch made in Iraq had dry density and moisture content of $1.51 \pm 0.02 \mathrm{~g} / \mathrm{cm}^{3}$ and $14.6 \mathrm{wt} \%$, respectively [26], while its particle size distribution varied from 35 to $75 \mu \mathrm{m}$.

Preparation of sawdust included drying in a furnace at $115^{\circ} \mathrm{C}$ for $3 \mathrm{~h}$ to eliminate the moisture, then grinding and sieving to obtain a powder with particle size less than $98 \mu \mathrm{m}$. Preparation of paper waste included passing the used paper through an apparatus of scrap paper-reduction several times to reduce its size, and then it was impregnated in water for $24 \mathrm{~h}$. After that, it was mixed using an electric mixer and left for one week to dissolve the paper in closed containers to prevent water vaporization; then, the paper pulp was hand pressed using a piston to remove excess water. Samples containing paper waste were formed by mixing the paper pulp with other powders and by mold method without the addition of water, where paper pulp worked as a binder material during the molding process. Kaolin clay powder was sieved to obtain a powder with particle size less than $74 \mu \mathrm{m}$; its density was 1.8 to 2.6 $\mathrm{g} / \mathrm{cm}^{3}$ [27]. After that, weighing and mixing of powders were done. A sensitive balance with a precision of 0.0001 g (Mettler, AE200) was used to carry out the weighing process. The weight percentages of powders used in this study are shown in Table III, where the fraction of the material used as a pore generating agent was $20 \%$ because this percentage gives an acceptable combination of the mechanical properties and porous structure for the samples, according to the literature [20,23]. The fraction of Na-feldspar was $25 \%$ for a reason mentioned above. An

Table I - Chemical composition (wt\%) of Iraqi kaolin clay.

[Tabela I - Composição química (\% em massa) da argila caulinítica iraquiana.]

\begin{tabular}{ccccccccc}
\hline $\mathrm{SiO}_{2}$ & $\mathrm{Al}_{2} \mathrm{O}_{3}$ & $\mathrm{MgO}$ & $\mathrm{TiO}_{2}$ & $\mathrm{Fe}_{2} \mathrm{O}_{3}$ & $\mathrm{CaO}$ & $\mathrm{Na}_{2} \mathrm{O}$ & $\mathrm{K}_{2} \mathrm{O}$ & LOI \\
\hline 47.4 & 38.5 & 0.3 & 0.1 & 0.5 & 0.3 & 0.3 & 0.6 & 12.0 \\
\hline
\end{tabular}

LOI: loss on ignition. 
Table II - Physical properties of Iraqi kaolin clay. [Tabela II - Propriedades físicas da argila caulinítica iraquiana.]

\begin{tabular}{cccc}
\hline Color & $\begin{array}{c}\text { Melting point } \\
\left({ }^{\circ} \mathrm{C}\right)\end{array}$ & $\begin{array}{c}\text { Density } \\
\left(\mathrm{g} / \mathrm{cm}^{3}\right)\end{array}$ & $\begin{array}{c}\text { Water } \\
\text { solubility }\end{array}$ \\
\hline Gray & 1770 & $1.8-2.6$ & Insoluble \\
\hline
\end{tabular}

Table III - Raw material composition (wt $\%$ ) of the samples. [Tabela III - Composição de matérias-primas (\% em massa) das amostras.]

\begin{tabular}{ccccc}
\hline Sample & A & B & C & D \\
\hline Kaolin clay & 75 & 55 & 55 & 55 \\
Sodium feldspar & 25 & 25 & 25 & 25 \\
Paper waste & 0 & 20 & 0 & 0 \\
Corn starch & 0 & 0 & 20 & 0 \\
Sawdust & 0 & 0 & 0 & 20 \\
\hline
\end{tabular}

electric mixer was used to carry out the mixing process. The samples were formed by mold method with the addition of $20 \%$ water (on the sample weight) as a binder material. The diameter of the formed samples was $30 \mathrm{~mm}$, and their thickness was $8 \mathrm{~mm}$. Specimens were dried initially in the air at room temperature for about $72 \mathrm{~h}$ and subsequently in a furnace at $115{ }^{\circ} \mathrm{C}$ for $5 \mathrm{~h}$, then fired at $1200{ }^{\circ} \mathrm{C}$ with a soaking time of $3 \mathrm{~h}$, and followed by furnace cooling.

Mechanical properties tests: the compressive strength was determined using a mechanical testing machine according to the ASTM C 773-88 standard, and the results were an average of 3 specimens tested for each prepared sample. Eq. A was employed to calculate the compressive strength $\left(\sigma_{c}, \mathrm{MPa}\right)[28]$ :

$$
\sigma_{\mathrm{c}}=\mathrm{P} / \mathrm{A}_{\mathrm{c}}
$$

where $\mathrm{P}$ is the applied load up to fracture $(\mathrm{N})$, and $\mathrm{A}_{\mathrm{c}}$ is the cross-section area of the specimen $\left(\mathrm{mm}^{2}\right)$. Vickers hardness was determined using a hardness tester with an indentation load of $89 \mathrm{~N}$ applied at about $8 \mathrm{~s}$ on polished surfaces of the specimens, considering an average of 3 indents for each of 3 specimens of each type of the prepared material. Vickers hardness $(\mathrm{HV}, \mathrm{MPa})$ values were calculated by [28]:

$$
\mathrm{HV}=1.854 . \mathrm{F} / \mathrm{d}^{2}
$$

where $\mathrm{F}$ is the applied load $(\mathrm{N})$, and $\mathrm{d}$ is the diagonal of the indentation on the specimen's surface $(\mathrm{mm})$.

Physical properties tests: the linear shrinkage was measured according to the ASTM C1407 standard, and the test results were an average of 3 specimens tested. Eq. C was used to calculate the specimens' linear shrinkage (LS, \%):

$$
\mathrm{LS}=\frac{\mathrm{D}_{\mathrm{b}}-\mathrm{D}_{\mathrm{f}}}{\mathrm{D}_{\mathrm{b}}} \cdot 100
$$

where $D_{b}$ and $D_{f}$ are the diameters of the specimen before and after the sintering, respectively. The Archimedes method was employed to determine the specimens' density. The specimens were boiled with distilled water for about $5 \mathrm{~h}$ to fill the voids. The specimens were cooled in the air at room temperature. The mass of the specimen immersed in water $\left(\mathrm{M}_{\mathrm{p}}, \mathrm{g}\right)$ and water-saturated mass $\left(\mathrm{M}_{\mathrm{S}}, \mathrm{g}\right)$ were measured. Then, the dry mass $\left(\mathrm{M}_{\mathrm{D}}, \mathrm{g}\right)$ was measured after drying the specimen in a furnace at $115^{\circ} \mathrm{C}$ for about $2 \mathrm{~h}$. The density of the specimens was calculated according to the ASTM C37388 standard using Eq. D and the results were an average of 3 specimens tested for each type of sample [29]:

$$
\mathrm{D}=\frac{\mathrm{M}_{\mathrm{D}}-\mathrm{D}_{\text {water }}}{\mathrm{M}_{\mathrm{s}}-\mathrm{M}_{\mathrm{P}}}
$$

where $\mathrm{D}$ is the bulk density of the specimen $\left(\mathrm{g} / \mathrm{cm}^{3}\right)$, and $\mathrm{D}_{\text {water }}$ is the density of water $\left(\mathrm{g} / \mathrm{cm}^{3}\right)$. Apparent porosity of the specimens was determined according to the ASTM C373-88 standard using Eq. E and the test results were an average of 3 specimens tested for each type of sample [29]:

$$
\mathrm{P}_{\mathrm{o}}=\frac{\mathrm{M}_{\mathrm{s}}-\mathrm{M}_{\mathrm{D}}}{\mathrm{M}_{\mathrm{s}}-\mathrm{M}_{\mathrm{P}}} .100
$$

where $\mathrm{P}_{o}(\%)$ is the open porosity of the specimen. Permeability test of the specimens was made, and the permeability values of water through the specimens were determined by Darcy's law (Eq. F), at $25{ }^{\circ} \mathrm{C}, 1 \mathrm{~atm}$, considering the viscosity of water of $0.890 \mathrm{cP}$, and the test results were an average of 3 specimens tested for each sample [30-32]:

$$
\mathrm{Q}=-\frac{\mathrm{K} \cdot \mathrm{A}}{\mathrm{L} \cdot \mu} \cdot \Delta \mathrm{P}
$$

where $\mathrm{Q}$ is the volumetric flow of the fluid $\left(\mathrm{cm}^{3} / \mathrm{s}\right), \mathrm{K}$ the permeability of the sample [darcy, $\mathrm{D}=\mathrm{cm}^{2} . \mathrm{cP} /(\mathrm{s} . \mathrm{atm})$ ], A the cross-sectional area of the sample $\left(\mathrm{cm}^{2}\right), \mathrm{L}$ the length of the sample $(\mathrm{cm}), \mu$ the viscosity of the fluid $(\mathrm{cP})$, and $\mathrm{P}$ is the pressure (atm).

Mercury intrusion porosimetry (MIP): the samples were tested by MIP to measure the distribution of pore sizes. MIP can give a pore size information over a wide range from 0.003 to $360 \mu \mathrm{m}$ according to a cylindrical capillary model. Mercury can enter the pores by applied external pressure. The measurements can be obtained from mercury intrusionextrusion curves, and then the pore information, including porosity, median pore size $\left(\mathrm{d}_{50}\right)$, average pore size $\left(\mathrm{d}_{\mathrm{a}}\right)$, and cumulative mercury injection volume, can be obtained. First, the specimens were dried in a furnace for $8 \mathrm{~h}$ at 110 ${ }^{\circ} \mathrm{C}$, then cooled to room temperature in a desiccator. Then, the MIP test was worked using a PoreMaster GT60 and the Washburn equation, supposing the pores with a cylindrical shape, was used according to [33]:

$$
\mathrm{P}=-\frac{2 \cdot \gamma \cdot \cos \theta}{\mathrm{R}}
$$

where $\mathrm{P}$ is the applied pressure (MPa), $\mathrm{R}$ the pore radius $(\mu \mathrm{m}), \gamma$ the mercury surface tension, set as $0.48 \mathrm{~N} / \mathrm{m}$, and $\theta$ the wetting contact angle, set as $140^{\circ}$ [34]. 
Microstructural analysis: the surface morphology of the porous ceramic specimens was analyzed by scanning electron microscopy (SEM).

\section{RESULTS AND DISCUSSION}

The tests made on the sintered samples were carried out to identify the appropriate material as a pore generating agent to manufacture a porous ceramic body with an excellent combination of mechanical and physical properties. Fig. 1 represents the effect of the type of the used material as a pore generating agent on the linear shrinkage, apparent porosity, and density of the sintered samples. The linear shrinkage of sample D, mixed with sawdust, was higher than the other samples: reference sample A, which did not contain a pore generating agent, sample B mixed with paper waste, and sample $C$ prepared with corn starch; the linear shrinkage of sample B was higher than those of the samples A and $\mathrm{C}$, and the linear shrinkage of the sample A was the lowest value. The shrinkage of the samples during the sintering process mainly occurs due to the loss of the moisture and the presence of a flux (sodium feldspar) in the sample composition which lead to forming a liquid phase during the firing process, and this liquid phase fill some of the voids between the particles and lead to reduce the volume of sample, causing the shrinkage $[35,36]$. Since the shrinkage of the samples B, C and D was due to the prior reasons, with the burn out of the used material as a pore generating agent during the sintering process, more voids were formed which were filled by the liquid phase, thus increasing the linear shrinkage of the samples [37]. The different values of the shrinkage of the samples B, $\mathrm{C}$, and $\mathrm{D}$ can be happened due to the difference in the burning process of the materials used and its results such as the ash content, which contains impurities related to its production process, and gases produced [26].

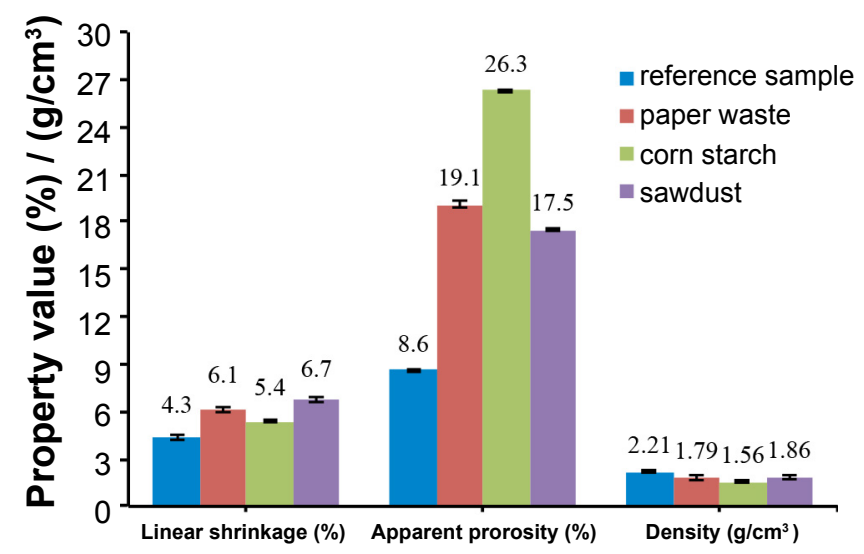

Figure 1: Linear shrinkage, apparent porosity, and density of sintered samples with different pore generating agent.

[Figura 1: Retração linear, porosidade aparente e densidade das amostras sinterizadas com diferente agente gerador de poros.]
The apparent porosity values obtained by the Archimedes method of the specimens A, B, C, and D were $8.6 \%, 19.1 \%$, $26.3 \%$, and $17.5 \%$, respectively (Fig. 1). So, sample C had the highest value of porosity, and sample A had the lowest value. A reason of the difference among the apparent porosity values of the sintered samples B, C and D can be ascribed to the different manners that the used materials as a pore generating agent burned out during the sintering process and left the pores in the fired samples, subsequently providing an increase in the total apparent porosity [38]. But in sample A, the pores were formed from the contact among the particles of the sample, which were not removed during the sintering operation. The results were in agreement with other studies $[20,23]$. Also, it can be observed from Fig. 1 that the ranking of sample's density from the highest to the lowest was the sample A, D, B and C. The difference in density values of the samples was caused by the formation of pores after the burning process of pore generating agent, which led to the decrease in the samples' mass and consequently a decrease of the density. In addition, all the used materials as a pore generating agent in this study had a density lower than that of kaolin clay (matrix material), which led to a decrease in the bulk density of the green samples and a distinctive difference between the sintered density of the sample A and the other samples $\mathrm{B}, \mathrm{C}$ and $\mathrm{D}$, due to the larger volume occupied by the pore generating agent than that of kaolin clay with the same weight [26]. In addition, the liquid phase formed during the firing process filled the voids between particles, which reduced the volume of the sample; consequently, it increased the sample's density $[35,36]$. A similar result was found by other authors $[20,23,39]$, using diverse starch contents and different preparation processes of the porous ceramic body.

Fig. 2 shows the effect of the type of pore generating agent on the permeability of the sintered samples. The permeability of the samples B, C and D was a higher than that of the sample $\mathrm{A}$ because of the increase in the number and volume of pore in the sintered samples B, C and D by adding a pore generating agent, which is an active method to increase the ceramic body permeation $[37,40]$. The permeability of sample B was higher than that of the samples $C$ and $D$, although sample $C$ had the highest porosity since most pores in this sample were not interconnected and the connectivity among them was less than that among the pores of the samples $\mathrm{B}$ and $\mathrm{D}$ because of the agglomerated shape of the starch particles [41, 42], as shown by the SEM image of sample C (Fig. 3c). In addition, the used materials as a pore generating agent in this study had different and wide range of the characteristics such as water and impurity contents, dry density, particle size distribution, and particle shape, which influenced the properties of the porous ceramic body in both the green and sintered states such as mechanical strength, density, porosity, and pore shape, size and distribution [26]. Finally, a reason of the difference in the permeability values between the samples $B$ and $D$ was related with the number and type of the formed pores, where the number of the closed pores formed in sample $\mathrm{D}$ was higher than that in sample B because of the characteristics of the sawdust used as a pore generating agent. 
Figs. $4 \mathrm{a}$ and $4 \mathrm{~b}$ represent the effect of the type of pore generating agent on the hardness and compressive strength of sintered specimens, respectively. Sample A had the highest values of compressive strength and hardness. The strength

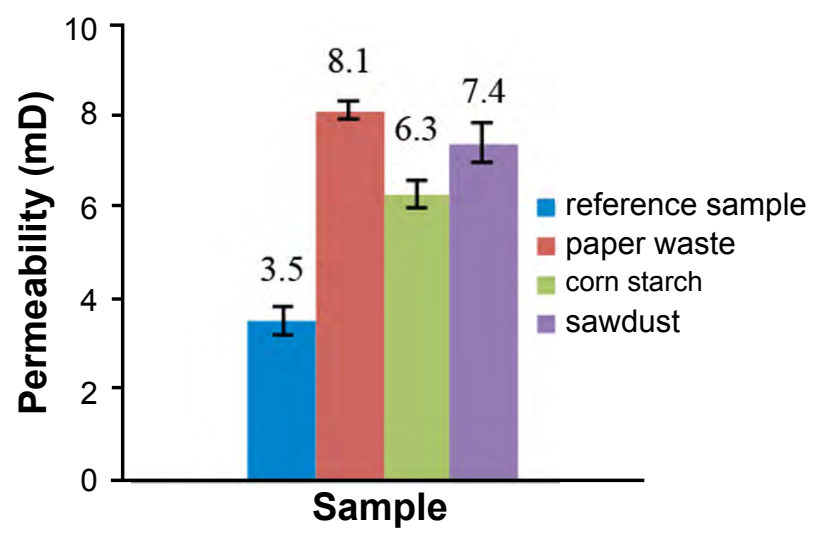

Figure 2: Permeability of sintered samples.

[Figura 2: Permeabilidade das amostras sinterizadas.]
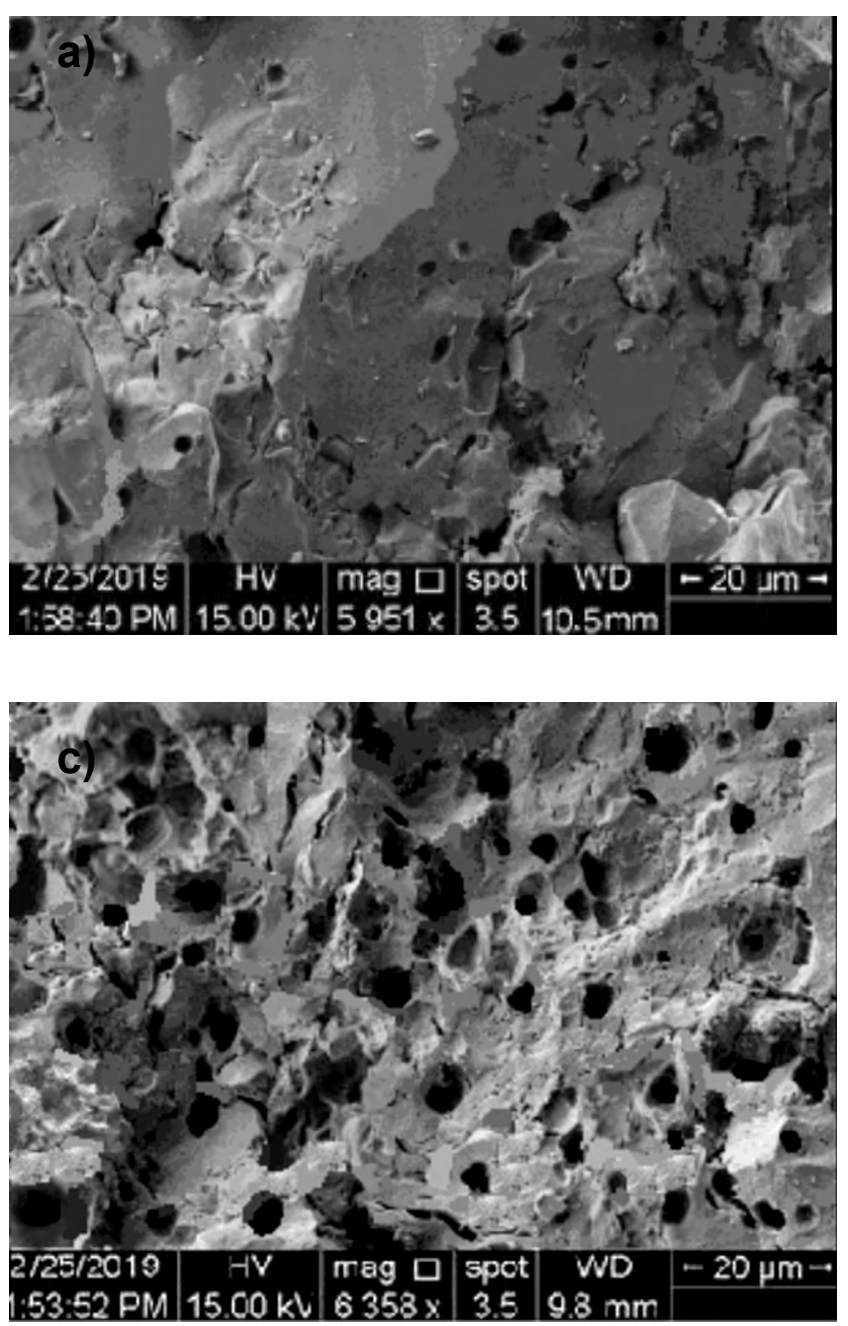

of a ceramic body depends on the existence of imperfections in it, such as pores, which are regions of stress concentration [43]. The volume of closed and open pores, as shown in Fig. 3 , caused the reduction of the compressive strength of the sintered specimens $\mathrm{B}, \mathrm{C}$ and $\mathrm{D}$, which was proportional to the apparent porosity [20,37].

Fig. 5 represents the cumulative porosity and relative pore volume (pore size distribution) of the sintered samples measured by the mercury intrusion porosimetry (MIP). Table IV shows the results of MIP measurements [44], specifically the total porosity and median pore diameter of the samples. The sample B mixed with paper waste had the highest MIP porosity, whereas the sample $\mathrm{C}$ mixed with corn starch had the highest value of the porosity obtained by Archimedes method since the most pores in this sample had less connectivity than the pores in the sample B. In addition, the sample $\mathrm{C}$ had the smallest size of pores due to the shape and size of the corn starch particles.

Figs. 3a, 3b, 3c, and $3 \mathrm{~d}$ show the micrographs of sintered specimens A, B, C, and D, respectively, obtained
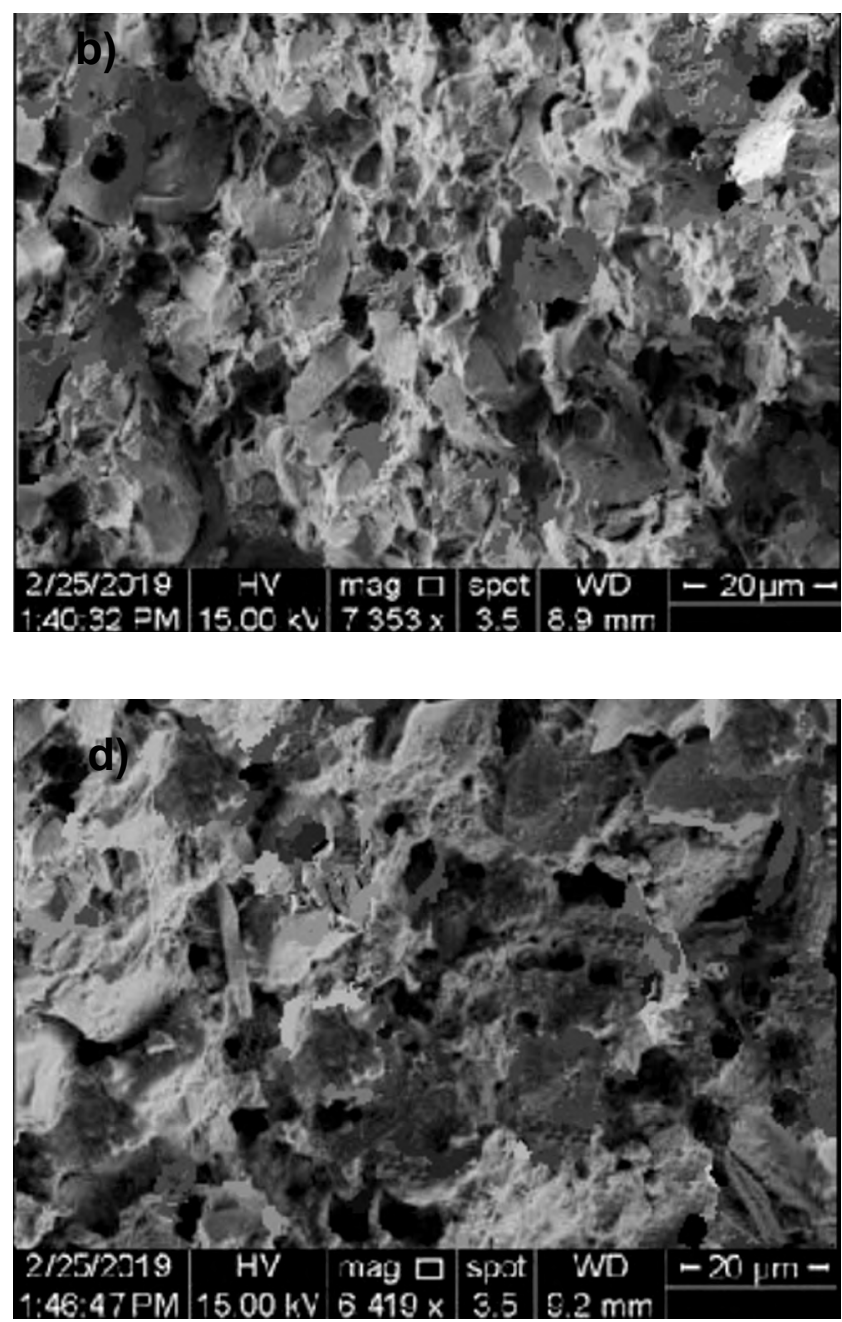

Figure 3: SEM images of the samples: a) A, not containing a pore generating agent; b) B, prepared with paper waste; c) C, prepared with corn starch; and d) D, prepared with sawdust, as pore generating agent.

[Figura 3: Imagens de MEV das amostras: a) A, não contendo agente gerador de poros; b) B, preparada com resíduo de papel; c) $C$, preparada com amido de milho; e d) $D$, preparada com serragem, como agente gerador de poros.] 

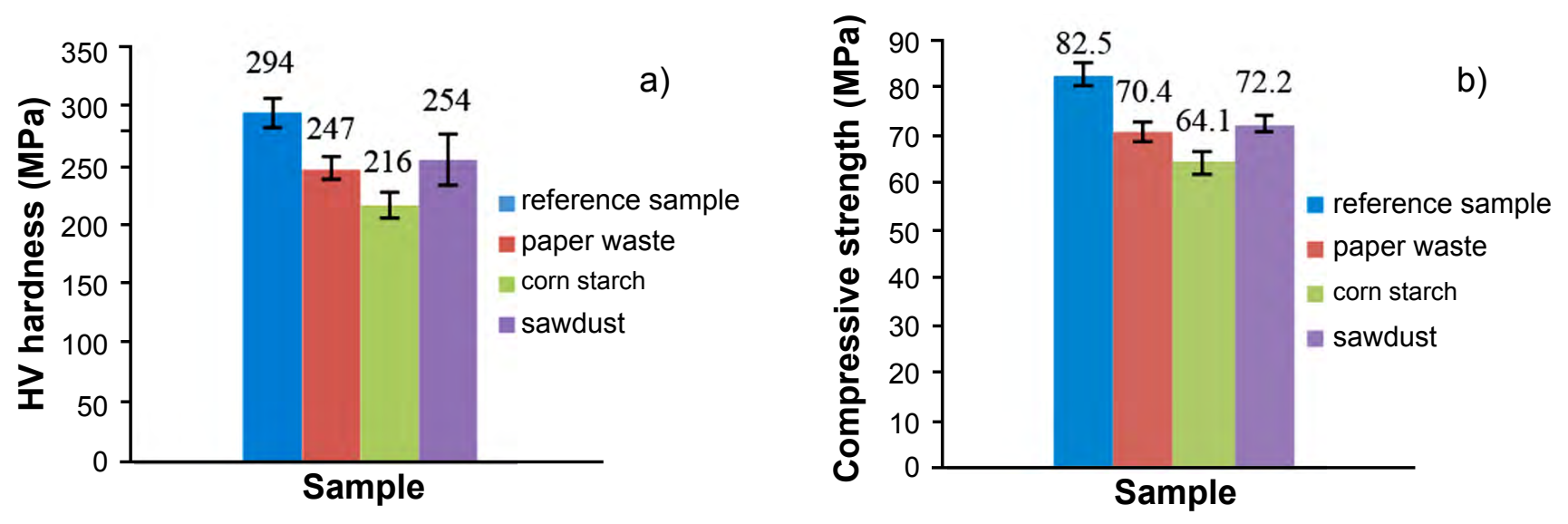

Figure 4: Effects of the type of pore generating agent on hardness (a) and compressive strength (b) of the sintered samples.

[Figura 4: Efeitos do tipo de agente gerador de poros na dureza (a) e resistência à compressão (b) das amostras sinterizadas.]
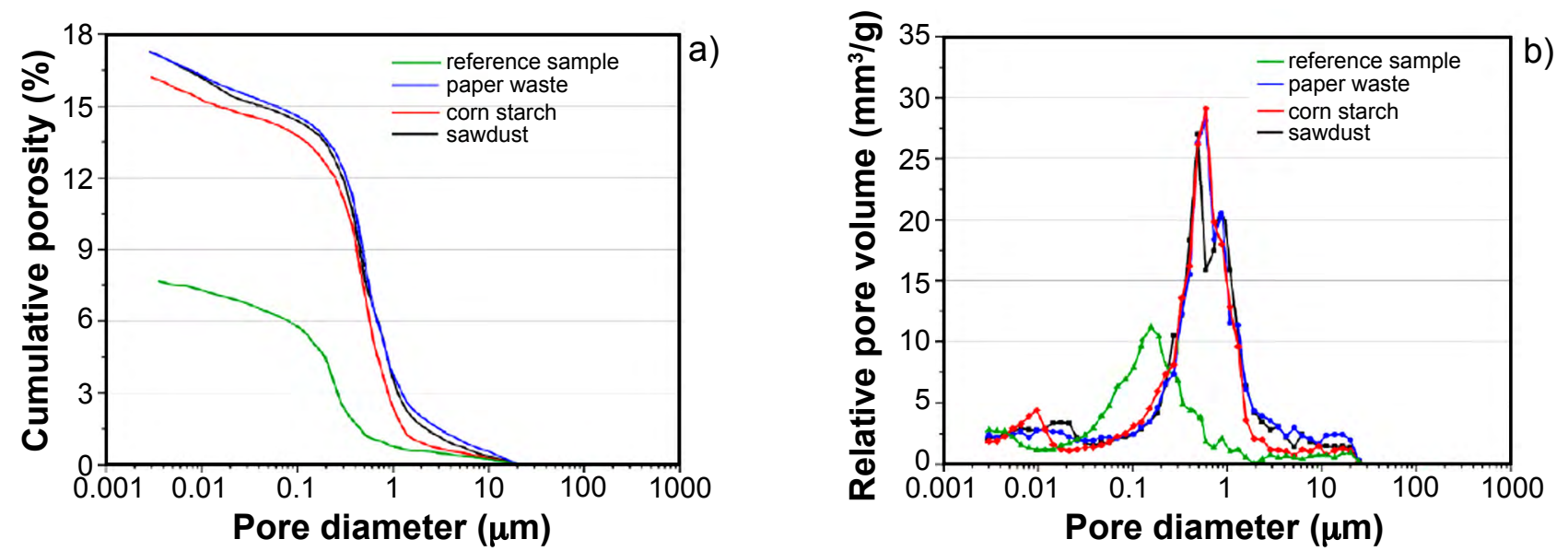

Figure 5: Cumulative porosity (a) and relative pore volume (b) as a function of pore diameter of the sintered samples.

[Figura 5: Porosidade acumulada (a) e volume de poro relativo (b) em função do diâmetro de poro das amostras sinterizadas.]

by scanning electron microscopy (SEM). Comparing the SEM images, more pores were noticed in the microstructure of the sintered sample C (Fig. 3c), showing that the added corn starch provided a more porous structure with lower connectivity among the pores and a good distribution of the pores compared to other samples. With respect to the porous structure of the other two samples, the paper waste in sample B provided a good porous structure with high connectivity among the pores in comparison with the sample D. The

Table IV - Results of mercury intrusion porosimetry (MIP). [Tabela IV - Resultados de porosimetria por intrusão de mercúrio.]

\begin{tabular}{ccc}
\hline Sample & $\begin{array}{c}\text { Total porosity } \\
(\text { vol\%) }\end{array}$ & $\begin{array}{c}\text { Median pore } \\
\text { diameter }(\mu \mathrm{m})\end{array}$ \\
\hline A & 7.5 & 0.15 \\
B & 17.1 & 0.71 \\
C & 16.0 & 0.53 \\
D & 17.0 & 0.67 \\
\hline
\end{tabular}

A: reference sample; $B$ : sample mixed with paper waste; $C$ : sample mixed with corn starch; D: sample mixed with sawdust.
SEM images confirmed the interpretation of the results of the other tests of the sintered samples. From the results of the tests, it could be stated that the sample prepared with the corn starch had the highest porosity, and the lowest mechanical properties and permeability, while the sample prepared with the sawdust had contrary results. Finally, the sample prepared with the paper waste had intermediate values of porosity and mechanical properties, and the highest permeability among the studied samples.

\section{CONCLUSIONS}

Comparing the low-cost porous ceramic samples manufactured using paper waste, corn starch, and sawdust as a pore generating agent, and a reference sample manufactured without a pore generating agent, it can be stated that the utilization of different materials as a pore generating agent increased the porosity and permeability depending on the characteristics of these materials, where the sample which contained the corn starch had the highest porosity, the lowest permeability, and minimum mechanical properties. On the contrary, the sample which contained the sawdust had the lowest porosity, the highest mechanical 
properties, and the intermediate value of permeability, while the sample which contained the paper waste had the intermediate values of porosity and mechanical properties and the highest permeability. In addition, the sample mixed with corn starch had the smallest pore size according to the results of mercury intrusion porosimetry. Consequently, the paper waste was the more suitable among the diverse cheap kinds of materials used as a pore generating agent in this study to manufacture a low-cost porous ceramic because it provided a preparation of a sample with a good combination of the mechanical properties, porosity, and permeability, which are considered the most important properties of the porous ceramic in application. In addition, the use of paper waste is beneficial to reduce its disposal, which is considered one of the environmental problems of solid wastes.

\section{REFERENCES}

[1] M.L.P. Antunes, A. Botignon de Sá, P.S. Oliveira, E.C. Range, Cerâmica 65, Suppl.1 (2019) 1.

[2] P.R. Monich, D. Desideri, E. Bernardo, Adv. Appl. Ceram. 118, 6 (2019) 366.

[3] A. Karamanov, Adv. Appl. Ceram. 108, 1 (2009) 14.

[4] H.R. Fernandes, D.U. Tulyaganov, J.M.F. Ferreira, Adv. Appl. Ceram. 108, 1 (2009) 9.

[5] I. Ponsot, R. Detsch, A.R. Boccaccini, E. Bernardo, Adv. Appl. Ceram. 114, Sup.1 (2015) S17.

[6] E. Gregorová, Z. Živcová, W. Pabst, Fruit Veg. Cereal Sci. Biotech. 3, Spec. Is. 1 (2009) 115.

[7] M. Scheffler, P. Colombo (Eds.), "Cellular ceramics: structure, manufacturing, properties and applications", Wiley-VCH, Weinheim (2005) 645.

[8] S. Ahn, K. Nam, J. Ceram. Process. Res. 18, 11 (2017) 767.

[9] L. Palmquist, K. Lindquist, C. Shaw, Key Eng. Mater. 333 (2007) 215.

[10] E. Chevalier, D. Chulia, C. Pouget, M. Viana, J. Pharm. Sci. 97 (2008) 1135.

[11] S. Vijayan, R. Narasimman, K. Prabhakaran, J. Eur. Ceram. Soc. 33 (2013) 1929.

[12] T. Zeng, X.L. Dong, S.T. Chen, H. Yang, Ceram. Int. 33 (2007) 395.

[13] A. Slosarczyk, E. Stobierska, Z. Paszkiewic, J. Mater. Sci. Lett. 19 (1999) 1163.

[14] S. Bose, C. Das, Mater. Lett. 110 (2013) 152.

[15] N. Seffaj, Y.S. Alami, M. Persin, M. Cretin,A. Albizane, A. Larbot, Ceram. Int. 31 (2005) 205.

[16] A. Majouli, S. Tahiri, Y.S. Alami, H. Loukili, A. Albizane, Ceram. Int. 38 (2012) 4295.

[17] E. Gregorova, W. Pabst, Ceram. Int. 33 (2007) 1385.

[18] H.M. Mahmudul, M. Shafiquzzaman, A.M. Shafiul, J. Nakajima, Desalination 276 (2011) 272.

[19] F.A.M. Rahim, M.Z. Noh, M.W.A. Rashid, J.J. Mohamed, M.A.A.M. Nor, AIP Conf. Proc. 2068 (2019) 20056.
[20] G.C.C. Yang, C. Tsai, Desalination 233 (2008) 129.

[21] J. Cao, X. Dong, L. Li, Y. Dong, J. Eur. Ceram. Soc. 34 (2014) 3181.

[22] S. Kitouni, A. Harabi, Cerâmica 57, 344 (2011) 453.

[23] S. Li, C. Wang, J. Zhou, Ceram. Int. 39 (2013) 8833.

[24] G. Topates, U. Petasch, J. Adler, F. Karaa, H. Mandal, J. Asian Ceram. Soc. 1 (2013) 257.

[25] E.M. Hadi, H.J. Abd Al-Hussien, Eng. Technol. J. 35, 1 (2017) 227.

[26] M.M. Lorente-Ayza, M.J. Orts, V. Pérez-Herranz, S. Mestre, J. Eur. Ceram. Soc. 35 (2015) 2333.

[27] J. Robert, L. Harold, Clays Clay Miner. 41, 4 (1993) 514.

[28] ASTM C773, "Standard test method for compressive (crushing) strength of fired whiteware materials", ASTM Int., West Conshohocken (1988).

[29] ASTM C373, "Standard test method for water absorption, bulk density, apparent porosity, and apparent specific gravity of fired whiteware products", ASTM Int., West Conshohocken (1988).

[30] A. Valconie, H. Natter, R. Hempelmann, Adv. Eng. Mater. 13 (2016) 218.

[31] G. Reyes-Villanueva, W. Cantwell, Compos. Sci. Technol. 64 (2015) 35.

[32] BS 1752, "Laboratory sintered or fritted filters", Br. Stand. Inst., London (1963).

[33] E.W. Washburn, Proc. Natl. Acad. Sci. USA 7 (1921) 115 .

[34] A.H. Ellison, R.B. Klemm, A.M. Schwartz, L.S. Grub, D.A. Petrash, J. Chem. Eng. Data 12 (1967) 607.

[35] K. Kim, J. Hwang, Ceram. Int. 41 (2015) 7097.

[36] E. Bernardo, P.A. Bingham, Adv. Appl. Ceram. 110 (2011) 41.

[37] B. Achiou, H. Elomari, M. Ouammou, A. Albizane, J. Bennazha, A. Aaddane, S. Alami Younssi, I. El Amrani El Hassani, J. Mater. Environ. Sci. 9, 3 (2018) 1013.

[38] R.M. Mesquita, A.H.A. Bressiani, Mater. Sci. Forum 727-728 (2012) 821.

[39] H.M. Alves, G. Tari, A.T. Fonseca, J.M.F. Ferreira, Mater. Res. Bull. 33 (1998) 1439.

[40] B. Achiou, H. Elomari, A. Bouazizi, A. Karim, M. Ouammou, A. Albizane, J. Bennazha, S. Alami Younssi, I.E. El Amrani, Desalination 419 (2017) 181.

[41] L. Palacio, Y. Bouzerdi, M. Ouammou, A. Albizane, J. Bennazha, A. Hernández, J.I. Calvo, Desalination 245 (2009) 501.

[42] S.A. Ajeel, N.E. Abdul Latiff, A.A. Al-Attar, Eng. Technol. J. 35, 9 (2017) 887.

[43] J. Chandradass, H.K. Kim, D. sik Bae, K. Prasad, G. Balachandar, S. Athisaya Divya, M. Balasubramanian, J. Eur. Ceram. Soc. 29 (2009) 2219.

[44] J. Raouf, W. Steffen, K. Dietmar, Fachbeiträge 156 (2017) 46.

(Rec. 24/10/2019, Rev.25/11/2019, 20/12/2019, 12/01/2020, Ac. $14 / 01 / 2020)$ 